\title{
The Perils of Internationalizing Higher Education: An Asian Perspective
}

\section{Philip G. Altbach \\ Philip G. Altbach is Monan professor of higher education and director of the Center for International Higher Education at Boston College.}

$\mathrm{T}$ his is the era of academic globalization. The developing countries, along with Eastern Europe, are experiencing a growing multinational trend-with foreign academic institutions, working with local institutions, or setting up shop on their own, offering academic programs and degrees "off the shelf" or based on models from Europe, the United States, or Australia. Distance education, using the Internet, is beginning to be used to deliver degrees. In a way, it is a repetition of colonial era imports of institutions and ways of thinking, but this time the foreigners are welcomed with open arms. It is time to stand back and assess the impact of the explosion of foreign higher education models in Asia.

The announcement in January that Sylvan Learning Systems-a for-profit American company so far mainly involved in selling test preparation, English-language, and other vocational programs in the United States and abroad - will set up universities overseas, starting with the purchase of a Spanish private university, is a signal that the Americans, so far slow to expand overseas, will enter the market. Hardly a week goes by without a critical article in the British press concerning the "demeaning" of traditional British academic standards overseas. Similar criticism is now heard in Australia, which has been a major exporter of academic programs to Asia.

Internationalism in higher education is hardly new. All of the world's universities do, after all, stem from medieval European institutions. In some cases, such as Japan, the Western model was adopted voluntarily. In many other countries, Western institutions were imposed under colonialism. For centuries, Latin was the common language of higher education. In the late 19th century, when universities entered the research arena, German was the main language of science. Now, English has become the Latin of the 21 st century, and is the most widely used medium of scientific communication and increasingly of intellectual discourse worldwide. There are well over a million students studying outside their home countries-the majority of them from Asia and studying in the United States, Britain, Canada, and Australia.

The current wave of internationalism has a late 20th century flavor. It is largely in the private sector. It is motivated by profits rather than by either government policy or goodwill. It is, for the most part, unregulated. The goals are to meet market demand and to create a market niche for an "educational product." Those providing the product, mainly academic institutions and other educational providers in English-speaking countries, are to a considerable extent motivated by a need to export in order to make up budget shortfalls at home.

There are a variety of educational products being sold. Foreign study remains a big business. The flows are largely from Asia to the West. Marketing is increasingly sophisticated, and despite the economic crisis in Asia, numbers continue to grow. Between 1996 and 1998, for example, the number of students going from Korea to the United States increased by 15.5 percent, from India by 10.4 percent, and from China by 10.5 percent. Japan, still the largest sending country to the United States, increased by just 1.7 percent, and Hong Kong declined by 11.7 percent. The United States hosts 481,000 overseas students, the large majority of whom pay all of their expenses. Related to foreign study are major ancillary industries devoted to teaching English and preparing students for a myriad of entrance examinations and other tests, assisting students with university applications and related formalities, student recruiting enterprises, and others. Most of these are entirely unregulated.

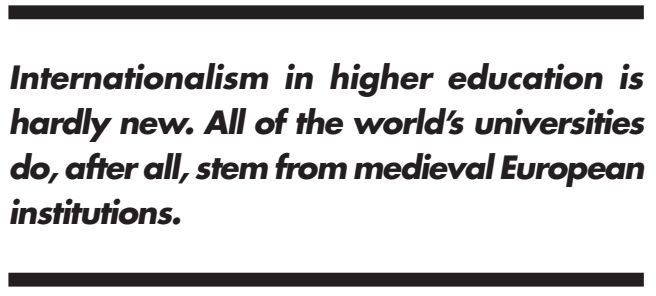

Universities from the industrialized nations are increasingly active in offering "offshore" degrees. Newspapers worldwide are full of advertisements for educational programs offered by foreign universities and other educational providers. Some renowned institutions offer offshore programs, as do a range of low-prestige schools or even "degree mills" that simply sell worthless and unrecognized certificates. Many models are available in today's educational marketplace-again, without regulation.

"Twinning" arrangements, in which a university in Asia or elsewhere links up with a Western institution, is a common way of offering offshore degrees. Local facilities and often local staff are used, along with some inputs from the Western sponsor. Often, a degree from the Western institution is awarded upon completion of studies. The curricular model, reading materials, pedagogical style, and usually the language of instruction of the Western institution are the core of the program, although there is little direct intellectual input from the host university. In this respect, the host institution is being "neocolonized." Stu- 
dents generally pay a significant premium for the privilege of studying the Western curriculum.

In some cases, the Western institution is integrally involved with all aspects of the educational program. In others, programs are "franchised," and there is little direct supervision or involvement by faculty from the "home" university. In a way, such operations are quite similar to McDonalds-an foreign vendor pays for using a "brand name" and must deliver a product designed abroad to local customers. Unlike McDonalds, quality control in the educational marketplace is spotty.

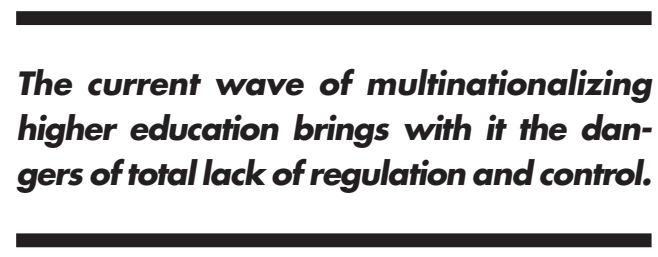

Increasingly, foreign educational providers are setting up shop in Asia and Eastern Europe without working with a local educational institution. Often, a business firm or entrepreneur invests resources to start an educational institution, and contracts with a Western university or other institution to provide the service and to award the degree. In some cases, a foreign institution will simply open a program. Again, there are few controls concerning quality, financial arrangements, or other details.

These are a few examples of the growing globalization of higher education. This phenomenon has many positive aspects. It helps serve rapidly growing demand for access to higher education. It stimulates cross-national educational innovation. It prepares students for work in a global economy. Yet, the multinationalization of higher education creates many challenges. Among them are;

- quality control-how can offshore providers be regulated and how can quality be ensured?

- information-who can tell which are worthwhile programs offered by reputable institutions and which are of low quality, sold just to make a quick profit?

- fit-do the programs meet a local need and do they contribute to the higher education system, and how do they related to local institutions?

- costs and benefits-are the programs worth what is charged for them?

These questions are difficult to answer. Measuring educational outputs is difficult in the best of circumstances. Fostering international cooperation and innovation in higher education is a good thing, and imposing too many controls may stifle new ideas. Yet, the current wave of multinationalizing higher education brings with it the dangers of total lack of regulation and control. It is a bad idea, in education at least, to permit caveat emptor to dominate.

\section{Jesuit Education: An International History}

\section{William B. Neenan, S.J.}

William B. Neenan, S.J. is vice president and special assistant to the president at Boston College. Address: 100 College Rd., Boston College, Chestnut Hill MA 02467 USA.

$\mathrm{T}$ he Society of Jesus early on has regarded education as a principal apostolate. In 1548 , only eight years after its founding, Ignatius Loyola, the first superior general, ordered a college to be opened in Messina, Sicily. Within a half century, several hundred Jesuit colleges had been established across Europe as well as in Lima, Mexico City, and Manila. Ignatius insisted that his followers be prepared on a moment's notice to go wherever they might better serve God. The age of discovery provided them with the occasion to do just that.

To trace this history, it is useful to divide Jesuit educational efforts into three eras: the age of discovery (15481763); the restoration of the Society of Jesus (1814-1960); and the age of globalization (after 1960). I will identify a few of the principal developments in each of these periods and conclude by identifying some challenges that face Jesuit education at the close of the 20th century.

Age of Discovery (1548-1763)

The Portuguese, Spanish, and French explorers of the 16th and 17 th centuries were often accompanied by Jesuits. These Jesuits exhibited the Ignatian insight that "God is to be found in all things," in their remarkable sensitivity to the languages, history, literature, and science of people who were often encountering Europeans for the first time. In addition to establishing their schools, Jesuits contributed significantly to the development of indigenous cultures. In the early 17 th century, Jesuit schools were the earliest disseminators of a literary culture in the Philippines through theatrical productions; and in the Paraguayan Reductions (1610-1767).

Jesuit scientists and mathematicians of the 16th and 17 th centuries, such as Matteo Ricci, interacted with Chinese scholars in the courts of the emperors. But this promising engagement between East and West was ill-starred. When the Chinese Rites, developed by Jesuits to accommodate Catholic liturgical practices to Chinese customs, were condemned by Roman authorities, Jesuit influence in the emperors' court cooled, and we are left with one of the great "what ifs" in history.

Then, in 1763, the Society of Jesus was suppressed by the Holy See. This action was taken under pressure from the Enlightenment rulers of Portugal, Spain, and Franceaided and abetted by the incompetence and venality of some Jesuit superiors. Thus ended two centuries of Jesuit educa- 